\title{
РЕФОРМИРОВАНИЕ ЗАКОНОДАТЕЛЬСТВА О НЕСОСТОЯТЕЛЬНОСТИ И ЕГО СОВРЕМЕННОЕ СОСТОЯНИЕ
}

\author{
(C) 2019 Муртазова Хеда Магомед-Салиховна
}

кандидат экономических наук, доцент кафедры экономики и управления в строительстве Грозненский государственный нефтяной технический университет, Чеченская Республика, Грозный E-mail: fu.ggni@mail.ru

\author{
(c) 2019 Ибрагимов Юсуп Муслимович \\ ассистент кафедры теории и технологии социальной работы \\ Чеченский государственный университет, Чеченская Республика, Грозный \\ E-mail:yusuf_ibr@mail.ru
}

В статье показано, как изменялось законодательство о банкротстве, его современное состояние, а также выявлены нормы процессуального права института несостоятельности (банкротства), которые регулируют процессуальные правоотношения банкротства. Эксплицирована необходимость совершенствования современного российского законодательства о банкротстве.

Ключевые слова: банкротство, институт несостоятельности, правоотношения, кредитор, должник.

Закон о банкротстве был принят в 2002 году. Впоследствии Закон о банкротстве изменялся довольно весомое количество раз, причем в него вносились как и незначительные изменения, так и кардинально меняющие концепцию Закона изменения. Например, 29 декабря 2014 года в Закон о банкротстве, а вместе с тем и в ряд кодексов, были внесены серьезные изменения в части регулирования реабилитационных процедур, применяемых к неплатежеспособным физическим лицам [3].

Институт несостоятельности (банкротства), в том виде, в котором он существует в настоящий момент, включает в себя нормы процессуального права, которые регулируют процессуальные правоотношения банкротства, связанные с возбуждением и рассмотрением судами дел о несостоятельности (банкротстве), а также и нормы гражданского, трудового и финансового права, которые регулируют возникающий в связи с возбуждением дела о банкротстве и введения процедур банкротства материально-правовой режим имущества должника и требований, предъявляемых к должнику по гражданско-правовым обязательствам, трудовым отношениям и обязательным платежам (налогам и сборам). Согласно мнению Карелиной С.А., законодательство о банкротстве нельзя назвать самостоятельной отраслью права, скорее нужно говорить о нем как о комплексном правовом институте [11], то есть о системе норм процессуального, граж-

данского, трудового и финансового права, связанных с правовым регулированием отношений, которые возникают по случаю несостоятельности (банкротства), в связи с чем, в отношении норм законодательства о несостоятельности (банкротстве) необходимо применять принципы и общие положения соответствующих отраслей права, точно также как и теоретические положения соответствующих отраслей права.

Вместе с этим, Закон о банкротстве включает в себя некоторые экономические и финансовые категории и понятия, вместо соответствующих им правовых категорий, что вносит дополнительные противоречия в регулирование рассматриваемых отношений. В частности, не имеют конкретного правового содержания такие финансово-экономические категории, как финансовое состояние должника, активы должника, фонды потребления, дебиторская задолженность и прочее. В свою очередь, гражданско-правовые категории, такие как «имущество», «имущественный комплекс», «предприятие как имущественный комплекс», «вид деятельности», «изменение вида деятельности», «прибыль», «убытки», «расходы», «обязательство», «долг», «задолженность», «требование» имеют вполне определенное содержание, за счет чего, посредством перечисленных гражданско-правовых категорий представляется возможным заменить обозначенные до этого финансово-экономические термины, что, в дальнейшем, не сможет не 
отразиться на эффективности правового регулирования отношений несостоятельности (банкротства).

Совокупность мер, направленных на совершенствование правового регулирования несостоятельности (банкротства), необходимо дополнить изменениями российского законодательства о банкротстве, которые будут направлены на выделение общих положений и правил о процедурах банкротства, закрепленных законодательством о банкротстве, распространяющихся на всех субъектов, которых в ряде случаев, возможно, признать банкротами. Специфику и различия банкротства граждан и юридических лиц в рамках такого подхода необходимо регламентировать в контексте отдельных разделов законодательства о банкротстве.

Существующая на данный момент редакция Закона о банкротстве по факту является законодательством о банкротстве юридических лиц, включающим в себя нормы об особенностях банкротства физических лиц. Рассматриваемый подход к правовому регулированию несостоятельности (банкротства) зиждется на нормах Гражданского кодекса РФ [1] (далее - ГК РФ) о несостоятельности (банкротстве), регулирующего несостоятельность (банкротство) физических и юридических лиц по отдельности. Общих норм о несостоятельности (банкротстве) в ГК РФ не имеется. Например, ст. 25 ГК РФ связана с несостоятельностью (банкротством) индивидуальных предпринимателей, а ст. 65 ГК РФ включает нормы о несостоятельности (банкротстве) юридических лиц.

Не имеется в ГК РФ и в Законе о банкротстве общих положений и правил о процедурах банкротства, распространяющихся на всех субъектов, которые могут быть признаны банкротами, что влечет неэффективность и неполноту правового регулирования несостоятельности (банкротства) граждан, в отношении которых правовое регулирование производится посредством установления определенных особенностей в отдельной главе, не давая возможности сформулировать в Законе о банкротстве общие положения и правила о процедурах банкротства для всех субъектов, которые могут быть признаны банкротами, а также мешая в полной мере учесть особенности банкротства граждан.

Учитывая перечисленные выше положения, нужно отметить, что существует реальная необходимость совершенствования современного российского законодательства о банкротстве, причем, осуществлять это нужно таким образом, чтобы общие положения и правила о процедурах банкротства распространялись на всех субъектов, которые могут быть признаны банкротами, а не только лишь на юридических лиц.

Законодательство о несостоятельности (банкротстве) в настоящее время представляет собой, пожалуй, одну из наиболее динамично развивающихся систем законодательного регулирования. Причем законодатель не акцентирует внимания на конкретном вопросе, требующем усовершенствования с точки зрения нормативного регулирования, а демонстрирует широкий круг проблем, входящих в поле зрения его интересов: это и проблемы, касающиеся банкротства граждан, привлечения к ответственности лиц, контролирующих должника, совершенствования механизма арбитражного управления, трансграничного банкротства и др. Не остаются без внимания законодателя и вопросы, которые в целом определяют цели, задачи института несостоятельности (банкротства) в рыночной экономике, а также правовые средства их реализации. Безусловно, в целом конструктивные усилия законодателя заслуживают одобрения. Вместе с тем не может не вызывать опасения порой бессистемное конструирование отдельных правовых норм и инструментария в механизме правового регулирования отношений несостоятельности (банкротства). Законодательство о несостоятельности (банкротстве) и правоприменительная практика в данной сфере представляют собой два важных фактора, оказывающие существенное влияние на формирование современного института несостоятельности (банкротства) и определение его места в рыночной экономике России. Данные факторы взаимодействуют друг с другом, причем на определенном этапе то один фактор, то другой оказывают приоритетное влияние на процесс развития института банкротства. Взаимодействие законодательства о несостоятельности (банкротстве) и правоприменительной практики осуществляется в различных формах, порой переходящих в явное противоречие, что негативным образом сказывается на достижении основной цели института несостоятельности (банкротства) и применимых средствах ее реализации. В этих условиях необходим системный, взвешенный подход к процессу совершенствования законодательства о несостоятельности 
(банкротстве), а также его разумное сочетание с правоприменительной практикой.

Наиболее оживленные научно-практические дискуссии в настоящее время возникают по поводу института банкротства граждан. Причем спектр тем для обсуждения достаточно широк: от очевидных проблем, связанных с реализацией арбитражного управления в процессе банкротства гражданина, до порой скрытых проблем, не лежащих на поверхности механизма правового регулирования отношений несостоятельности с участием граждан, а именно касающихся цели института банкротства граждан и эффективности реализации данного института. Не секрет, что граждане-должники все чаще используют институт банкротства для недобросовестного уклонения от исполнения своих обязательств, а сам институт банкротства граждан стал прочно ассоциироваться с громкими банкротными процессами Б.А. Кехмана, Т. Исмаилова и др. С момента первого в России прецедента не освобождения должника-гражданина от обязательств по результатам процедуры банкротства прошло уже около полутора лет. Определением Арбитражного суда Новосибирской области от 24 марта 2016 г. по делу № A45-24580/2015 гражданин В.А. Овсянников был признан банкротом, но не освобожден от обязательств, поскольку «принял на себя заведомо неисполнимые обязательства, что явно свидетельствует о его недобросовестном поведении в ущерб кредиторам» [9]. Именно с этого момента начала формироваться соответствующая негативная для должников судебная практика, связанная с неприменением механизма освобождения от обязательств, которая вновь поставила перед законодателем вопрос об основной цели института банкротства граждан. Аргументация, используемая арбитражными судами при неприменении механизма освобождения от обязательств, достаточно разнообразна. Наиболее часто встречающееся основание для не освобождения от долгов можно условно обозначить как «заведомая неисполнимость обязательств», когда должник изначально понимает, что не сможет указанные обязательства обслуживать. Это основание было использовано судом в вышеупомянутом деле о банкротстве гражданина Овсянникова, а также в некоторых других [6].

Определенной вариацией на данную тему является ссылка судов на факты сокрытия должником от кредитора информации о размере уже имеющейся долговой нагрузки [8]. Достаточно часто используемым основанием для не освобождения от обязательств на практике применялось положение, в соответствии с которым должник не располагал достаточным количеством имущества для реализации процедур банкротства. На этом фоне вызывает интерес законопроект № 307663-7 «О внесении изменений в Федеральный закон «О несостоятельности (банкротстве)» и отдельные законодательные акты Российской Федерации» [10]. Примечательно, что данный законопроект добавляет к цели процедуры реализации имущества, применяемой в отношении гражданина, наряду с удовлетворением требований кредиторов, освобождение от обязательств. При этом закрепляется правило, согласно которому отсутствие у гражданина имущества, которое могло бы быть после покрытия расходов на процедуру, применяемую в деле о банкротстве гражданина, направлено на удовлетворение требований кредиторов, не препятствует введению процедуры, применяемой в деле о банкротстве гражданина. Означает ли это, что практика применения положений п. 4 ст. 213.28 заставляет законодателя внести существенные изменения в сферу нормативного регулирования, признав, что помимо соразмерного удовлетворения требований кредиторов у института банкротства граждан есть еще и социально-реабилитационная цель, которая достигается списанием долговых обязательств с одновременным установлением системы ограничений для должника, предусмотренных ст. 213.30 Закона о банкротстве? Представляется, что да. Причем указанная позиция относительно правовой природы института банкротства граждан находит свое подтверждение в последней правоприменительной практике, например, в Определении ВС РФ от 23 января 2017 г. № 304ЭС16-14541 по делу № А70-14095/2015 [7].

Еще один вопрос, требующий пристального внимания и законодателя, и правоприменителя, это вопрос о привлечении к субсидиарной ответственности контролирующих должника лиц, который, надо признать, привлекает внимание законодателя уже не в первый раз. Речь идет о Федеральном законе от 28 декабря 2016 г. № 488-Ф3 «О внесении изменений в отдельные законодательные акты Российской Федерации» [2]. В настоящее время законодатель расширяет возможности закрепления за лицом статуса контролирующего должника, прежде всего, за 
счет расширения оснований возникновения отношений контроля, в частности легализации понятия фактического контроля. Помимо этого, законодатель в ответ на вызов правоприменителя предусмотрел возможность реализации двух моделей привлечения к субсидиарной ответственности: в рамках процесса банкротства и в так называемый постбанкротный период, т.е. уже после прекращения производства по делу. В целом усилия законодателя по расширению возможностей реализации концепции «снятия корпоративной вуали» следует поддержать. Вместе с тем ответ на вопрос о том, насколько такие законодательные возможности по привлечению к субсидиарной ответственности контролирующих должника лиц позволят повысить эффективность института банкротства на практике, остается открытым. Более того, и законодателю, и правоприменителю не следует забывать о том, что механизм привлечения к субсидиарной ответственности контролирующих должника лиц должен применяться лишь в случаях, прямо предусмотренных законом, как исключение из действия общего принципа разделения ответственности юридического лица и его участников (учредителей), предусмотренных ст. 56 ГК РФ. В противном случае мы можем столкнуться с негативными проявлениями законодательных новелл, деструктивно влияющих на процесс развития рыночных отношений в России.

В настоящее время существенную проблему представляет вопрос осуществления мер по предупреждению банкротства банков. В первую очередь проблема заключается в том, что суды различных инстанций зачастую не рассматривают отношения, связанные с предупреждением банкротства банков, как охватываемые законодательством о банкротстве. Так, в частности, по одному из дел, связанных с защитой прав вкладчиков ПАО «Национальный банк «ТРАСТ», суды трех инстанций давали неправильную оценку указанным правоотношениям. И только ВС РФ в своем Определении от 27 октября 2017 г. указал, что «по смыслу абз. 12 ст. ст. 2, 31 и 189.9 Закона о банкротстве санация (меры по предупреждению банкротства) представляет собой одну из предбанкротных процедур, являющихся неотъемлемой частью отношений, связанных с несостоятельностью кредитных организаций» [5]. На практике возникает еще одна проблема, связанная непосредственно с реализацией механизма предупреждения банкротства банков. Так, за- частую вводится временная администрация без должного анализа финансового состояния должника, а план участия Агентства по страхованию вкладов в предупреждении банкротства кредитной организации не содержит каких-либо положений о формах и объеме финансовой помощи, которая будет оказана со стороны Агентства (п. 4 ст. 189.15 , ст. 189.49 Закона о банкротстве). Как показывает практика, уже нередки случаи, когда временная администрация вводилась в день обращения Банка России в Агентства с предложением принять участие в мероприятиях по предупреждению банкротства банка. Заметим, что ВС РФ указал в упомянутом выше Определении, что «реализация отраженной в плане санации стратегии проведения реабилитационных мероприятий по существу направлена на восстановление платежеспособности кредитной организации в рамках предбанкротной процедуры с учетом той особенности, что утверждение плана отнесено к компетенции Банка России (Комитета банковского надзора и при определенных условиях Совета директоров Банка России - п.п. 2 и 3 ст. 189.49 Закона о банкротстве), осуществляющего публичные полномочия в отношении участников банковского рынка, что обусловлено принципиальным значением данного рынка как базового для всей экономики в целом». Представляется, что введение временной администрации на основании п. 7 ч. 1 ст. 189.26 является формально законным решением, поскольку минимальные сроки анализа финансового состояния банка, принятия Агентством предложения об участии, разработки Агентством плана участия и его утверждения Банком России законодателем не закреплены. Однако Закон о банкротстве и ведомственные акты устанавливают как к Банку России, так и к Агентству требование, чтобы участие Агентства в осуществлении мер по предупреждению банкротства было целесообразным. С учетом этого, представляется, что план санации должен содержать положения о формах и объемах финансовой помощи. Однако сам выбор конкретных форм и объема оказания финансовой помощи является дискреционным полномочием Банка России и Агентства. Такое возможно, поскольку меры по предупреждению банкротства включают в себя не только оказание финансовой помощи, но и исполнение функций временной администрации, организацию торгов и иные (ст. 189.49 Закона о банкротстве). Выбор каждой меры должен обусловливать- 
ся разумным соотношением с иными мерами, предусмотренными планом участия. Оказание финансовой помощи банку должно соответствовать ключевой характеристике участия Агентства в мероприятиях по предупреждению банкротства: целесообразности.

Отсутствие четкой позиции законодателя по данному вопросу не является единственным при практической реализации механизма предупреждения банкротства банков. Зачастую на практике возникает вопрос: допустим ли отзыв лицензии у кредитной организации до мотивированной отмены ранее принятого решения Комитета банковского надзора Банка России не отзывать лицензию и не применять меры, предусмотренные ст. 74 Федерального закона «О Центральном банке Российской Федерации (Банке России)» [4]? Представляется, что ответ на данный вопрос очевиден: в силу п. 6 ст. 189.49 Закона о банкротстве «в случае принятия решения об отказе в утверждении плана участия Агентства в осуществлении мер по предупреждению банкротства банка или в случае невозможности выполнения указанного плана, в том числе в результате невыполнения указанного плана банком, Банк России отменяет решения, принятые в соответствии с пунктом 13 статьи 189.47 настоящего Федерального закона».

С учетом изложенного, думается, необходимо закрепление четкой позиции и законодателя и правоприменителя по вопросу о том, что недопустим отзыв лицензии у кредитной организации до мотивированной отмены ранее принятого решения Комитета банковского надзора Банка России не отзывать лицензию и не применять меры, предусмотренные ст. 74 Федерального закона «О Центральном банке Российской
Федерации (Банке России)». Иной подход к применению соответствующих норм может дискредитировать саму идею возможности реализации механизма предупреждения банкротства банков.

Это, безусловно, далеко не все вопросы, которые требуют в настоящее время повышенного внимания законодателя. Вместе с тем они с бесспорностью доказывают тот факт, что на современном этапе развития института несостоятельности (банкротства) необходим системный, взвешенный подход к процессу совершенствования законодательства в данной сфере, который реально способствовал бы повышению эффективности данного института.

Делая выводы необходимо отметить, что правовой институт несостоятельности (банкротства) представляет собой неотъемлемую составляющую системы правового регулирования экономической деятельности, причем, особое место в таком регулировании он занимал еще с давних времен. Законодательство о банкротстве существует, главным образом, с целью восстановления платежеспособности должника, а также справедливого и соразмерного удовлетворения требований всех его кредиторов.

Развитие и совершенствование правового регулирования несостоятельности (банкротства) находится в тесной связи с развитием гражданского и коммерческого права, процесса и судопроизводства. В то же время, уже на самых первоначальных этапах своего становления институт банкротства представляет собой особый комплекс специальных норм как материального, так и процессуального права, которые призваны регулировать основания, порядок и последствия банкротства.

\section{Библиографический список}

1. Гражданский кодекс РФ (часть первая) от 30.11.1994 № 51-ФЗ // СЗ РФ, 1994, № 32, ст. 3301

2. Федеральный закон от 31.12.2014 № 488-Ф3 «О промышленной политике в Российской Федерации» // С3 РФ, 2015, № 1 (часть І), ст. 41.

3. Федеральный закон от 29 декабря 2014 г. № 476-ФЗ «О внесении изменений в Федеральный закон «О несостоятельности (банкротстве)» и отдельные законодательные акты РФ в части регулирования реабилитационных процедур, применяемых в отношении гражданина-должника» // Российская газета. № 299. 2014.31 дек.

4. едеральный закон от 10.07.2002 № 86-ФЗ «О Центральном банке Российской Федерации (Банке России)» // СЗ РФ, 2002, № 28, ст. 2790.

5. Определение Верховного Суда РФ от 27.10.2017 № 305-КГ17-9802 по делу № А40-17830/2017 // СПС Гарант.

6. Постановление Арбитражного суда Московского округа от 30 июня 2017 г. по делу № А40-96462/2016 // СПС Гарант. 
7. Определение Верховного Суда РФ от 23.01.2017 № 304-ЭС16-14541 по делу № А70-14095/2015 // СПС Гарант.

8. Постановление Арбитражного суда Уральского округа от 16 декабря 2016 г. № Ф09-11353/16 по делу № A71-5858/2015 // СПС Гарант.

9. Определение Арбитражного суда Новосибирской области от 24 марта 2016 г. по делу № A45-24580/2015 // СПС Гарант.

10. Паспорт проекта Федерального закона № 307663-7 «О внесении изменений в Федеральный закон «О несостоятельности (банкротстве)» и отдельные законодательные акты Российской Федерации» (в части усиления социально-реабилитационной функции института банкротства граждан и расширения сведений, публикуемых в федеральном информационном ресурсе) // СПС Гарант.

11. Карелина С.А. Механизм правового регулирования отношений несостоятельности. М.: Волтерс Клувер, 2008. 